\title{
複列河道における 小規模洪水時の流量把握手法の提案
}

\author{
野間口 芳希 1 ・中村 詩穂 2 ・秋田 麗子 1 ・手計 太-3 \\ 1 正会員 日本工営株式会社 河川水工部（干102-8539 東京都千代田区九段北 1 丁目 14 番 6 号) \\ 2 正会員 日本工営株式会社＼cjkstart砂防部（广102-8539 東京都千代田区九段北 1 丁目 14 番 6 号） \\ 3 正会員 富山県立大学 工学部（广939-0398 富山県射水市黒河 5180）
}

E-mail:a7345@n-koei.co.jp

\begin{abstract}
平成27年の黒部川の出し平ダム・宇奈月ダムによる連携排砂において, 河口地点でADCPを用いた流量 観測を実施した。その結果, 約 $13 \mathrm{~km}$ 上流の愛本観測所に比べて流量波形が約 1 時間遅れることや, 複列河 道における流路毎に流量の相違することを把握した.

流量観測にあたっては, 高流速用ボートの採用, 往復観測の実施，水深に応じた計測対象流路の選別， 他観測手法との組み合わせによる効率化，濁度による減衰状況の把握などを実施した。電波流速計で計測 した表面流速とADCPで実測した断面平均流速の関係性は既存の更正係数と同程度となり，地形と水深が 既知であれば, 表面流速の計測によって精度よく流量換算が可能であることを把握した。これらの知見を 踏まえ, 今後の複列河道における流量観測手法の省力化・省コスト化に向けた提案を行った.
\end{abstract}

Key Words : field observation, Acoustic Doppler Current Profiler(ADCP), streamflow observation, multiple row stream, Electronic current meter, Coefficient of float

\section{1. はじめに}

黒部川の宇奈月ダム (多目的ダム，平成13年竣工，国 土交通省管理)では，比堆砂量 $2,500 \mathrm{~m}^{3} / \mathrm{km}^{2} / \mathrm{year}$ という活 発な土砂流入によるダム堆砂の急激な進行を抑えるため, その豊かな水量を活かし，同じく排砂ゲートを有する上 流の出し平ダム(発電専用ダム，昭和 40 年竣工，関西電 力株式会社管理) と，連携排砂運用を行っている. 連携 排砂時には，ダム下流河道の複数地点において同時浮遊 砂観測が実施されるなど，土砂流出を人為的に制御する ことによる環境への影響が継続的に監視されている.

黒部川の最下流に位置する下黒部橋 (0.6k付近)におい ても採水調査が実施され，連携排砂中の浮遊砂濃度のピ 一ク值，フラックス等が議論されてきた。 一方で，浮遊 砂のフラックス評価に用いられる河川流量は，慣例的に 上流の愛本観測所 (13.4k付近，扇頂部の単列河道)で計測 されたものが用いられてきた．これは，下黒部橋地点は， (1)広く浅い流れが特徵の複列河道であり，流路毎に独立 した流れが形成されている，(2)急流河川で小規模洪水時 でも $4 \mathrm{~m} / \mathrm{s}$ 程度の高流速が発生する，(3)連携排砂中は平均 して $5,000 \mathrm{mg} / \mathrm{L}$ 上回る高濁度となる，という現地条件 から，流量観測には不適と考えられてきたためである.
このため，慣例手法では愛本観測所からの流下距離に 応じた流量波形の遅れや流路毎の流量の相違を反映した 評価ができず，下黒部橋地点における流量実態を把握す ることが積年の課題となっていた.

高椋ら ${ }^{1)}$ は，この下黒部橋において，平成23年連携排 砂時に， ADCP(超音波ドップラー流速分布計) $)^{2)}$-4)や電波 式流速計占を用いた流速分布の計測を行い，高流速・高 濁度下であっても流量把握が可能であることを示した. 一方で，低水路幅 $500 \mathrm{~m}$ の 中に大小合わせて全4本の流路 があり全てを観測対象としたが，そのうちADCPによっ て良好に計測できたのは水深 $1.5 \mathrm{~m}$ 以上となる流路1～2本 であったこと，計測できた流路においても，高流速や流 下物の影響により欠測データがしばしば発生していたこ となど，ADCPの観測に要した労力やコストの割に，得 られた成果が限定的であることが課題として残った。

筆者らは，平成27年連携排砂時に再び同地点において 流量観測を実施するにあたり，上記の経験を踏まえ，近 年，流路位置が固定化しているという現地条件に着目し， 事前にADCPの適用範囲を見定め, より精度よく, かつ 効率的に観測するための実務的な方法を試みた。ささらに, 今回の計測結果を踏まえると，今後はADCPを用いずと も，より省力的な流量把握ができる可能性を把握した. 


\section{2. 現地観測概要}

\section{(1) 観測地点}

観測を実施する黒部川は，黒部ダムをはじめとした発 電ダム群があり (図-1参照), 下流の出し平ダム, 宇奈月 ダムにおいて，連携排砂を実施している.

流量観測は，黒部川0.6k付近の下黒部橋地点で実施し た(図-2参照)。0.6k測線および下黒部橋直下における横 断測量結果を図-3に示す．観測箇所には4つの流路があ り，主流路は右岸寄りに位置する，本稿では，左岸側よ りSubA，SubB，SubC， mainとして各流路を称する.

\section{(2) 観測項目および観測手法}

平成27年7月連携排砂期間中に，表-1に示寸項目につ いて観測を行った.

電波式流速計による表面流速計測は，各流路を網羅す るよう9 地点(観測地点(1)〜9)において測定を実施した。

ADCPによる計測については，橋上より高流速に対応 したトリマランB型ボート (最大流速 $6 \mathrm{~m} / \mathrm{s}$ 程度まで観測可 能) 凤固定したADCPを横断方向に曳航して実施した(図 -4参照)。このとき，ADCPの横断方向への移動速度は, 平成23年計測時と同じく $0.5 \mathrm{~m} / \mathrm{s}$ とした ${ }^{1)}$ 。 $\mathrm{ADCP}$ の計測モ ードは高流速に適したハイスピードピンギングモード (Mode 12)，計測層厚を $0.20 \mathrm{~m}$ ，層数を 35 ，不感帯幅を計 測層厚と同様 $0.20 \mathrm{~m}$ とした，観測間隔は2.0secとし，1ア ンサンブルについて3回超音波を発信した。 このとき， 計算される計測誤差は， $0.03 \mathrm{~m} / \mathrm{s}$ となる (表-2参照).

また，平成23年調査で明らかになった課題1 を踏まえ た改善策としては以下のとおりである.

(1)小水深時 $(1.5 \mathrm{~m}$ 以下) の観測精度が劣ることを踏まえ

て, 水深 $1.5 \mathrm{~m}$ を目安とし, 観測時刻毎に計測対象 とする流路を選別した。

(2)片道1回の観測では，高流速や流下物等の影響で欠 測がしばしば発生し，補正が困難であることを踏 まえて，往復で2回観測を実施した。

(3)電波式流速計の観測地点を5点から9点に増設し, 各 流路で複数のデータが得られるようにすることで 代表流速の精度向上を図った。

(4)電波式流速計，ADCP ともに観測回数を大幅に増加 し，時間方向の密度を増やした(前回 : 8回，2〜5 時間毎 $\rightarrow$ 今回 : 24回，1３時間毎).

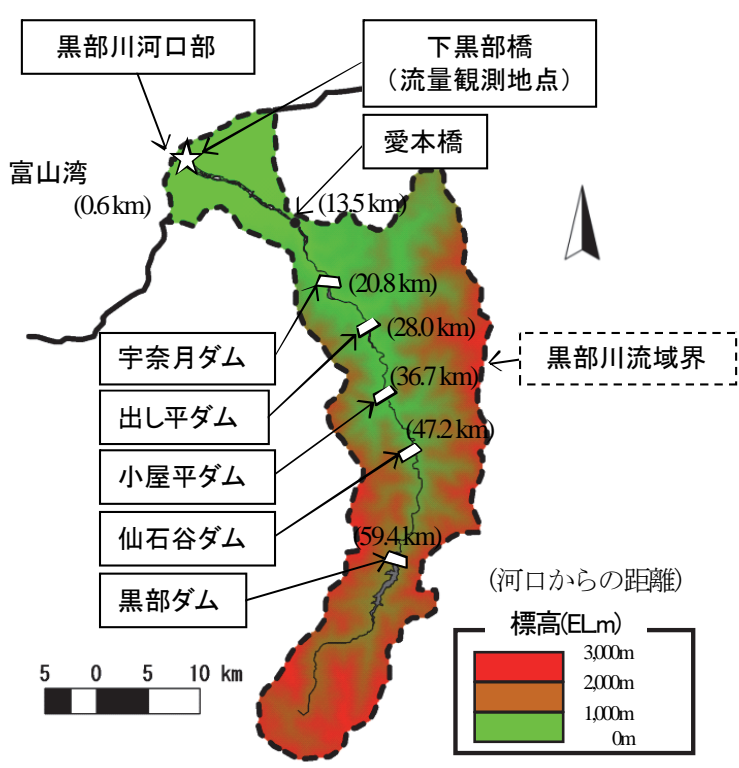

図-1 流域概要

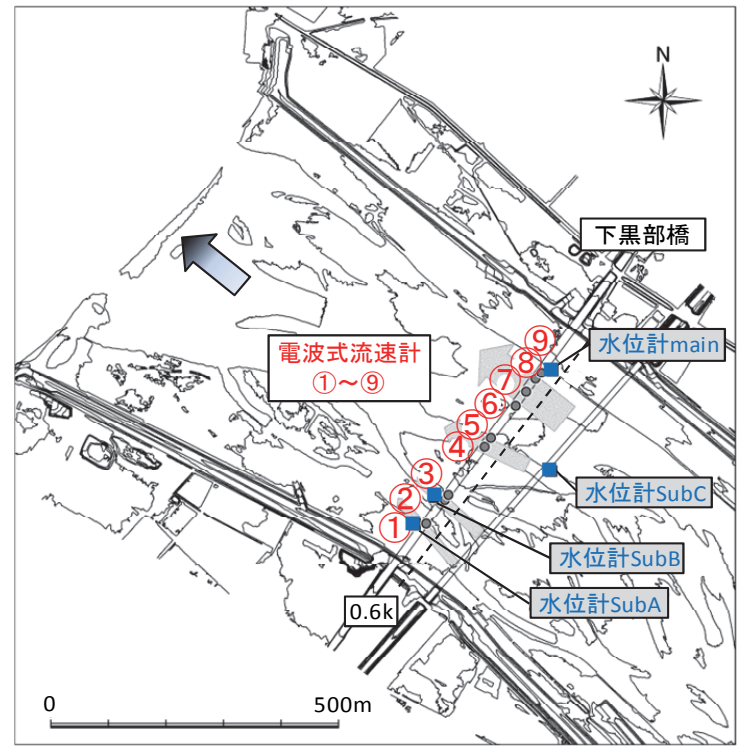

図-2 観測地点 (平面)

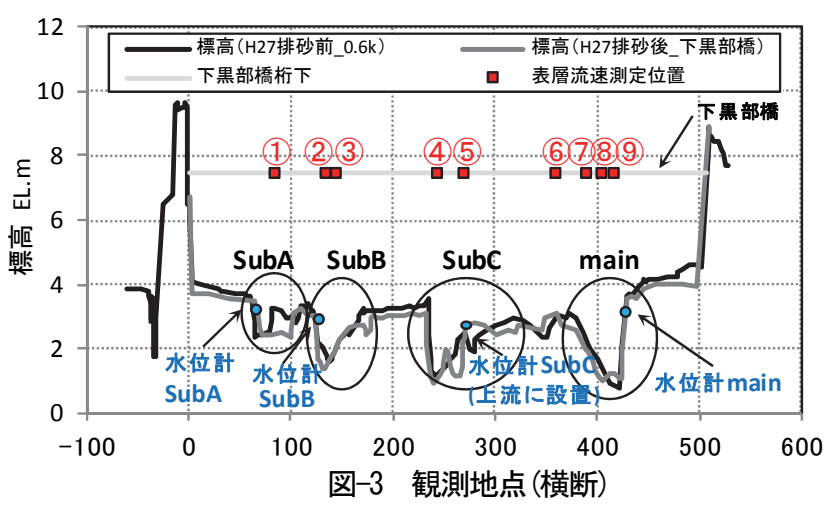

表-1 観測項目

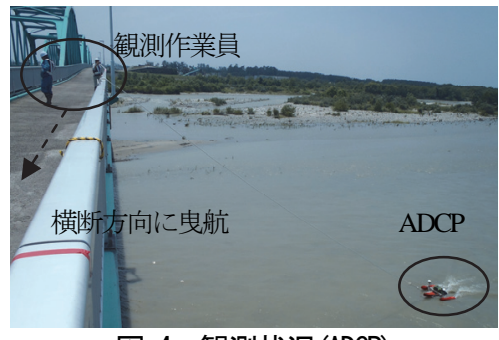

\begin{tabular}{|c|c|c|c|}
\hline 観測項目 & 観測機器 & 観測ピッチ & 観測方法 \\
\hline 水位 & $\begin{array}{c}\text { 圧力式水位計 HOBO } \\
\text { (Onset社製) }\end{array}$ & 5分 & みお筋毎に設置 \\
\hline \multirow[b]{2}{*}{ 流速 } & $\begin{array}{c}\text { 電波式流速計 Ryukan } \\
\text { (横河電子機器株式会社製) }\end{array}$ & $1 \sim 3$ 時間 & 下黒部橋上から測定 \\
\hline & $\begin{array}{c}\text { ワークホース ADCP } \\
\text { (Teledyne RD Instruments社製) }\end{array}$ & $1 \sim 3$ 時間 & $\begin{array}{l}\text { 高流速対応型ボートを } \\
\text { 使用し下黒部橋上か } \\
ら \text { ら往復で測定 }\end{array}$ \\
\hline 表層採水 & バケツ & 1 3時間 & 橋上から採水 \\
\hline 中間層採水 & 羽根付採水器 & 1 3時間 & " \\
\hline 全層採水 & 層別直接採取管 & $1 \sim 3$ 時間 & $\begin{array}{l}\text { バックホウに機器を取 } \\
\text { り付け左右岸から採水 }\end{array}$ \\
\hline
\end{tabular}

表-2 ADCP の設定

\begin{tabular}{|l|c|}
\hline Mode & 12 \\
\hline Sampling Interval & $2.0 \mathrm{sec}$ \\
\hline Pings/Ens & 3 \\
\hline Bin Size & $0.20 \mathrm{~m}$ \\
\hline Bins & 35 \\
\hline blank & $0.20 \mathrm{~m}$ \\
\hline Standerd Dev. & $0.03 \mathrm{~m} / \mathrm{s}$ \\
\hline BT Mode & 5 \\
\hline BT pings/Ens & 3 \\
\hline
\end{tabular}




\section{3. 現地観測結果}

\section{(1) 平成27年連携排砂の概要}

連携排砂中の降雨量, 宇奈月ダムの流入量 - 放流量 貯水位を図-5に示寸．平成27年6月30日より降り出した 降雨により，7月1日9時11分に出し平ダムにおいて排砂 基準流入量の $250 \mathrm{~m}^{3} / \mathrm{s}$ を記録し，連携排砂実施が決定した。 同日15時40分から宇奈月ダムの水位低下が開始されたこ とを受けて，筆者らは，7月1日18時より流量観測を開始 した.

\section{（2） 観測実施概要および流況}

流量観測は，この7月1日18時から，連携排砂における
「水位低下 $\rightarrow$ 自然流下 $\rightarrow$ 水位回復 $\rightarrow$ 排砂後の措置」の一 連の操作期間を網羅し，7月3日9時20分の宇奈月ダムに おける排砂後の措置完了を受け，同日12時に流量観測を 完了するまで1時間〜3時間間隔で計24回実施した (図-6 下段参照)。観測期間中は大きな降雨もなく，風速も最 大 $3 \mathrm{~m} / \mathrm{s}$ 程度であり，作業性には特段の問題はなかった。

各流路における水位，水深，流速の時間変化を図-6に 示寸．流路毎に水位が異なっており，それぞれが独立し た流れになっていることがわかる．水位回復期には水深 $1.5 \mathrm{~m}$ を回るものの，全体として水深1.5mを超える時間 帯が最も多いmain流路のみADCPによる測定を実施した. 流速についても，main流路の流速が水深低下時を除き他 流路に比べて大きくなっており，主流となっている.

宇奈月ダムの操作

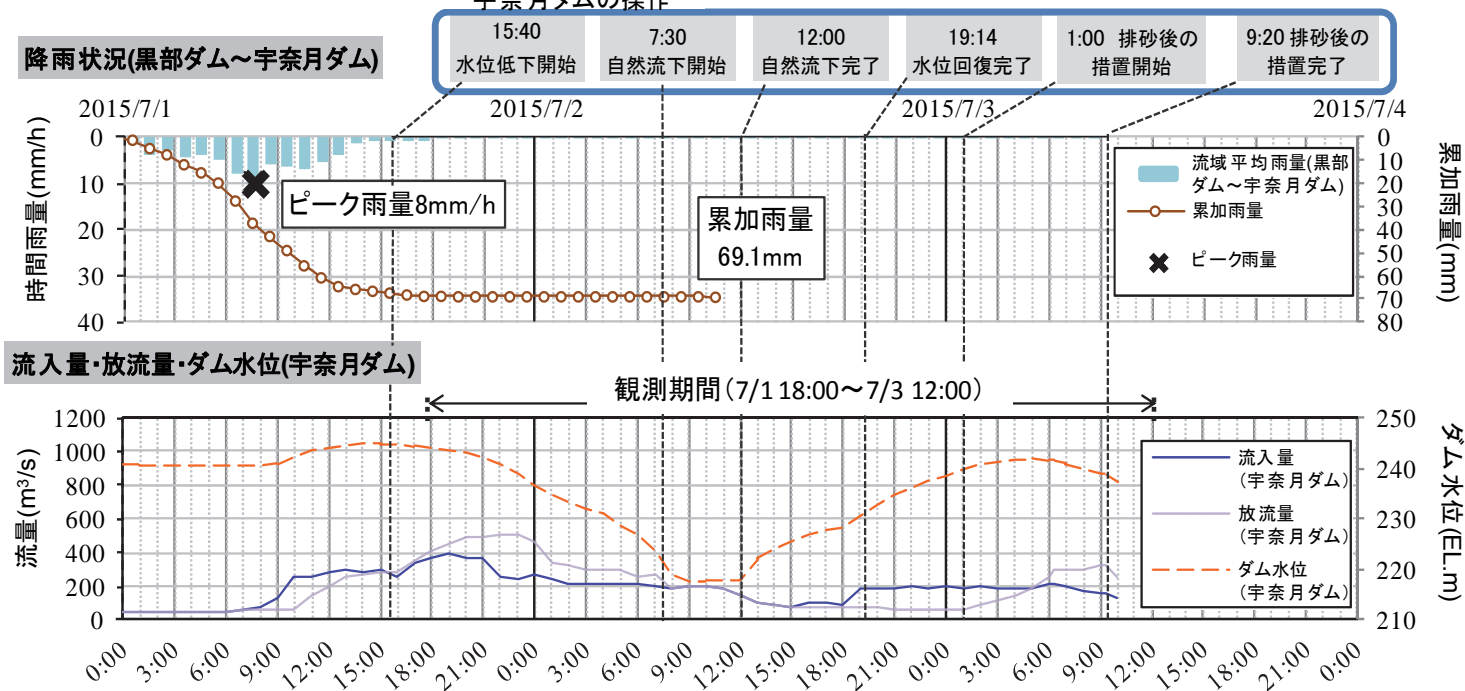

\section{水位(下黒部橋)}

図-5 排砂時の状況 (上段 : 雨量, 下段 : 宇奈月ダムの諸量)

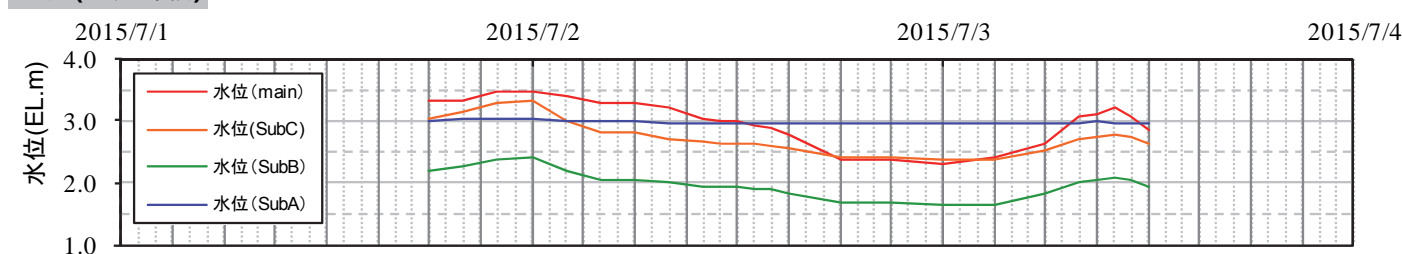

\section{水深(下黒部橋)}
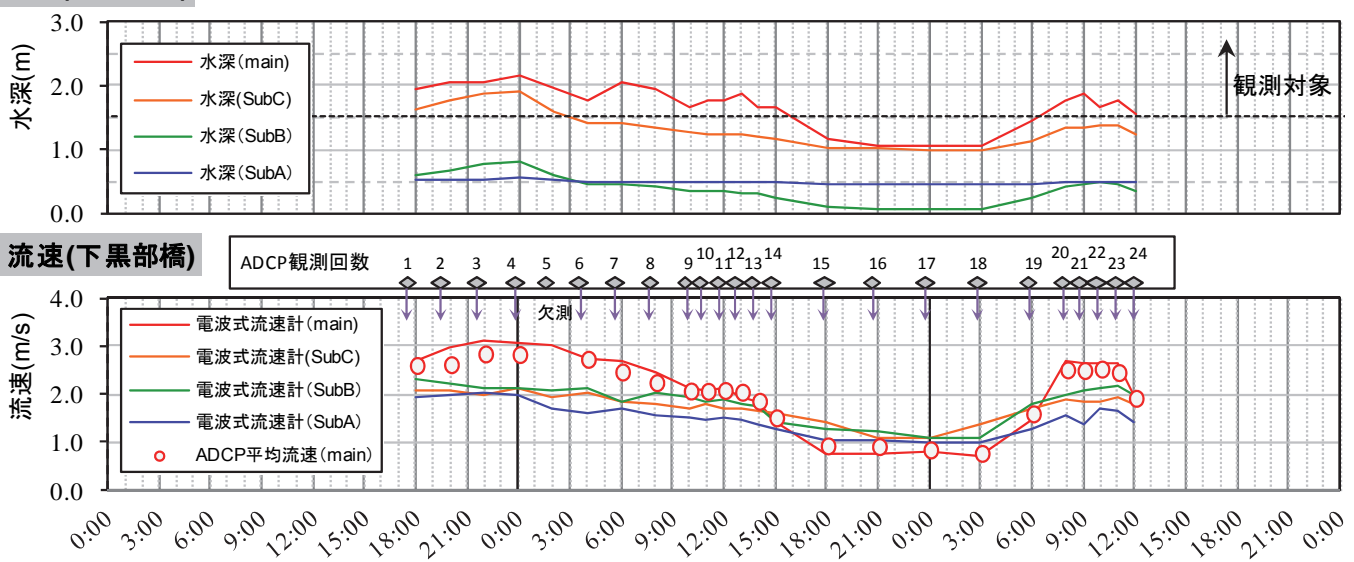

図-6 下黒部橋地点の流況 (上段 : 水位，中段 : 水深，下段 : 流速) 
(3) 流速観測結果

(a) ADCPIよる流速分布

ADCPで観測したmain流路の流速分布を図-7に示寸. 観測期間内における表層の最大流速は $4.5 \mathrm{~m} / \mathrm{s}$ であった.

$\mathrm{ADCP}$ で測定した流速鉛直分布の妥当性検証の一つと して, 理論值との比較を行ったものを図-8に示す．理論 值は二瓶ら ${ }^{7)}$ の検討を踏まえ, 対数分布則（I=1/200, $\mathrm{n}=0.045$ ）を用いて算出した．比較は図-7に示す3地点（観 測地点(7)(8))において行った. 観測地点(9は一部でピ アの影響による流れの乱れがあるが，全般的には観測值 と理論值はほぼ一致した。

\section{(b) 表層流速と表面流速の比較}

次に, main流路における異なる計測手法による流速観 測結果の比較を行った. 図-9の左図に3地点 (観測地点(7) 899)において電波式流速計で測定した表面流速および,
同地点でのADCPの表層流速の推移を示寸. 図-9の右図 はその比較であり, 両者はほぼ一致している。

(c) 水深平均流速

流量算定において必要なデータは河積および断面平均 流速であるが、電波式流速計は表面流速のみを測定する ため, 水深平均流速への変換が必要である. 図-10に, main流路中央部の観測地点8において，ADCPにより得 た水深平均流速, 電波式流速計により得た表面流速, こ れらより逆算した更正係数を示す．観測精度が劣る水深 が小さい時間帯を除くと, 更正係数は平均 0.89 となり, 時間によるばらつきも小さい，これは，表面流速用の標 準値として用いる更正係数 0.85 とほぼ一致しており ${ }^{8)}$ 、 表面流速を適切に計測できれば、更生係数をもとに水深 平均流速に換算できることを把握した.

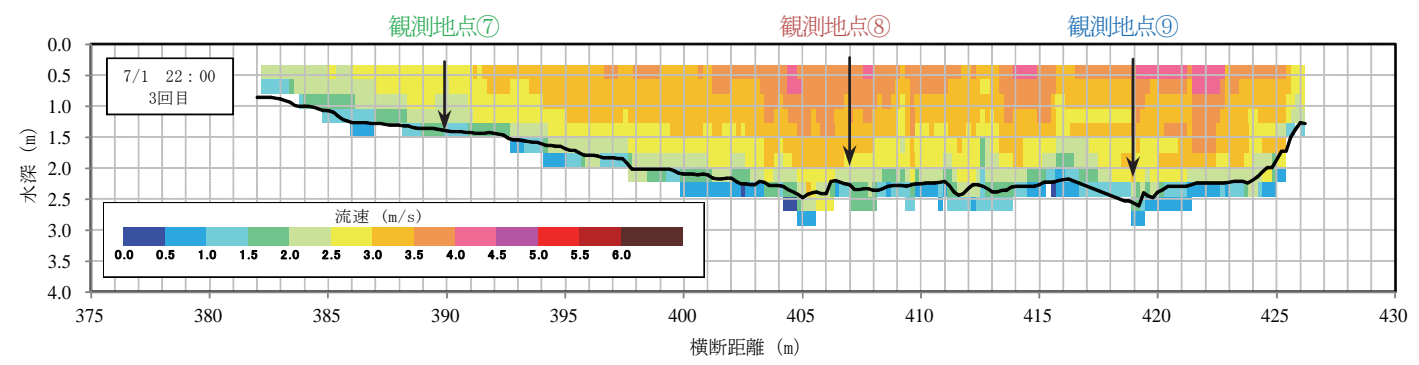

図-7 流速分布 (main 流路)
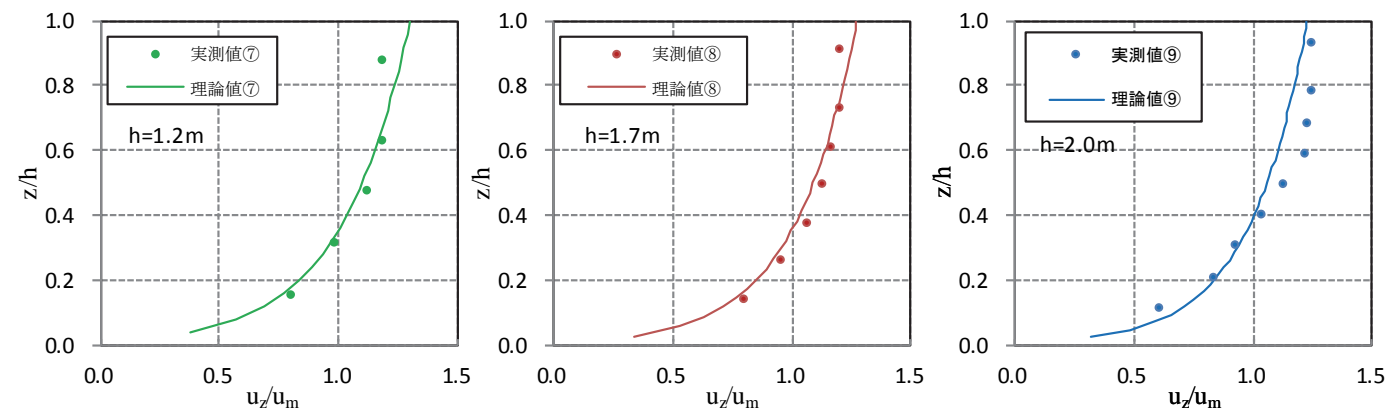

図-8 無次元流速鉛直分布の観測値と理論値 (観測地点77899)
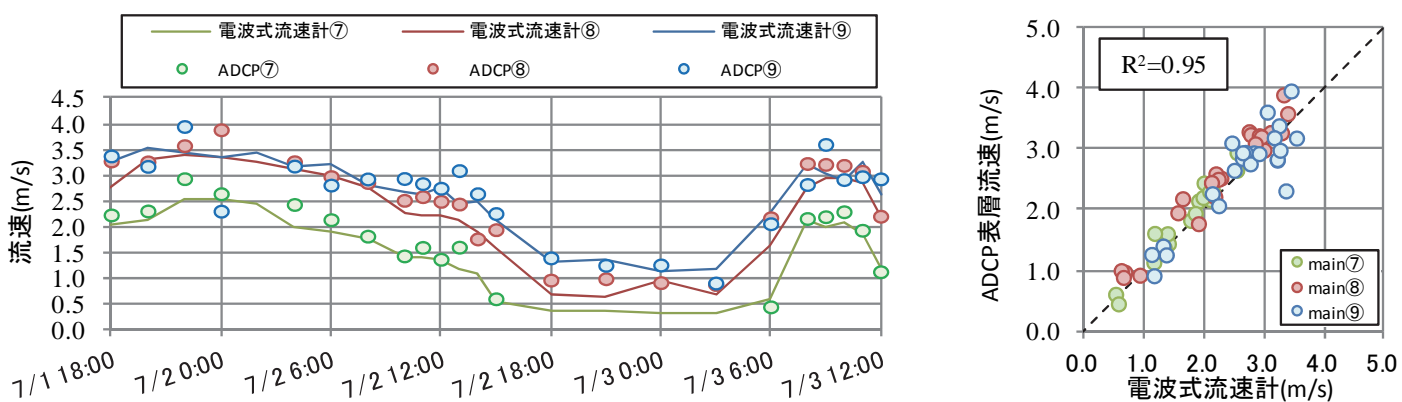

図-9＼cjkstart表面流速と表層流速(観測地点(7)899)

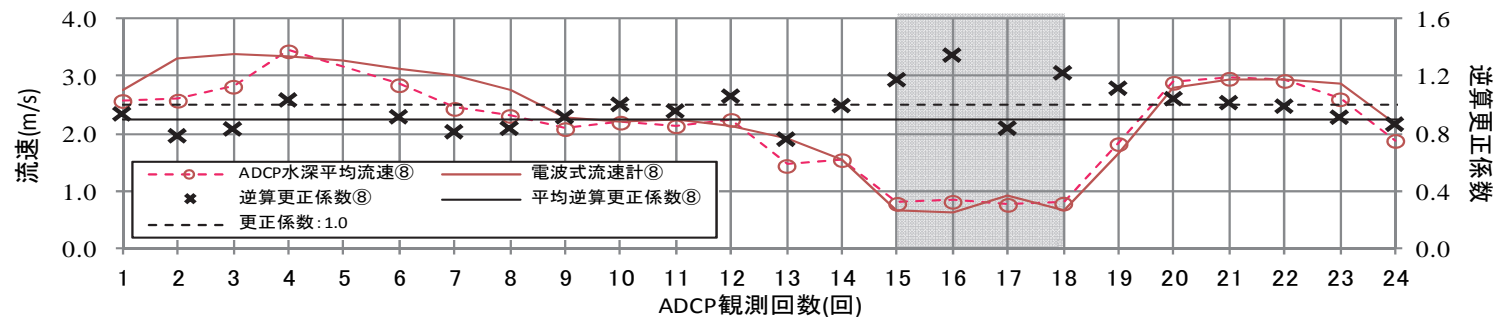

図-10 逆算更正係数 (観測地点8) 


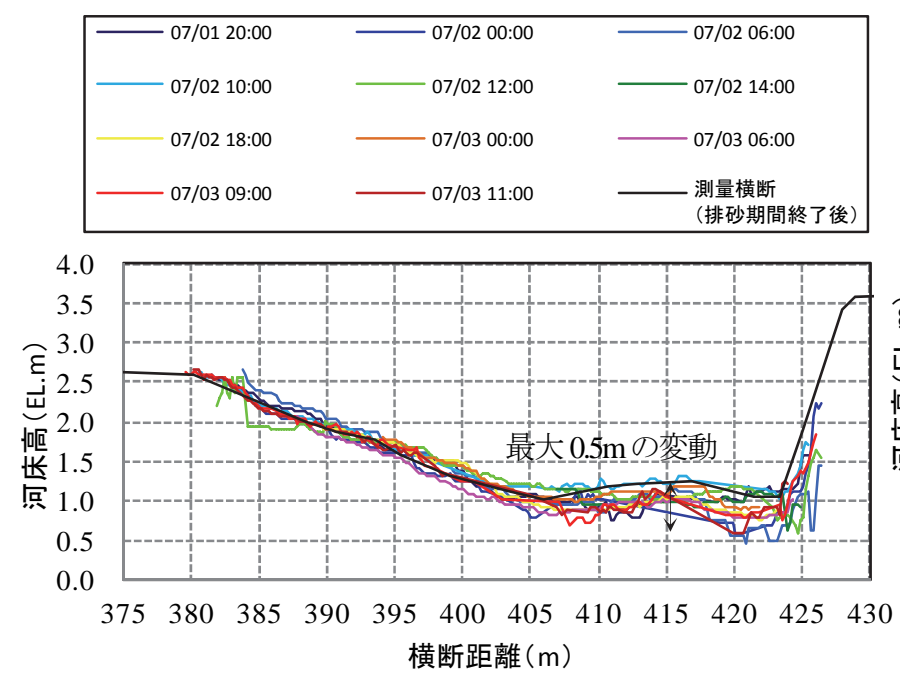

図-11 main 流路の河床変動状況

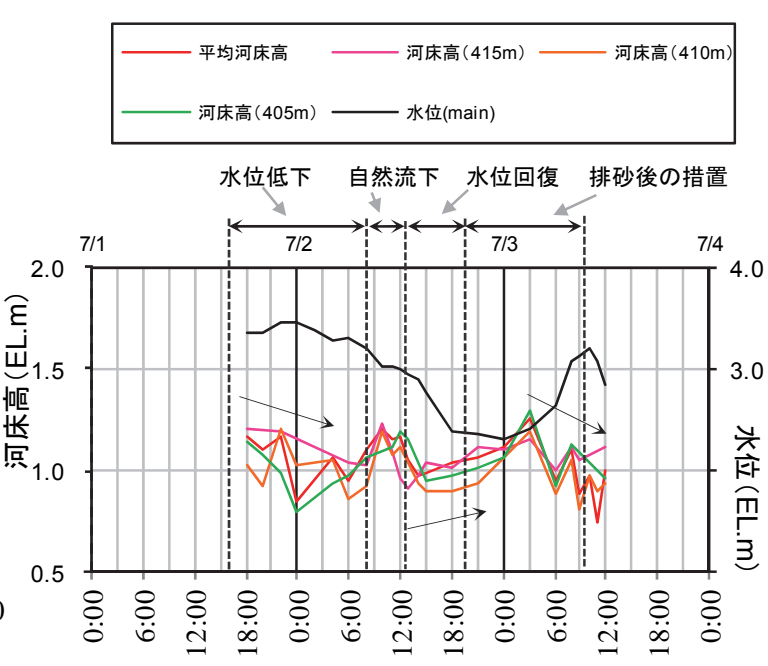

図-12 河床位の推移

\section{(4) 河道地形の変化}

図-11に，ADCPにより得た水深と，別途実施した水位 計のデータを用いて求めたmain流路(横断距離 $375 \mathrm{~m}$ 430m)における河床横断形状の変化を示寸. 図-12には任 意地点での河床位の時間的推移を示す，流量の大きい水 位低下時には河床が低下し，その後の流量低減時には 徐々に河床が上昇し，排砂後の措置を開始して流量が再 び増大している期間に，河床は最も低くなる状況が確認 でき，その河床変動量は最大でおよそ $0.5 \mathrm{~m}$ 程度であった

なお，ADCP定点観測において確認した河床変動の測 定誤差は最大 $\pm 0.1 \mathrm{~m}$ 程度であり, 高流速対応型ボートを 使用したことにより良好にデータを取得できたと考える。

\section{4. 流量の推定}

\section{（1） 流量の算定方法}

ADCPおよび電波式流速計による流速観測結果を用い, 表-3に示寸手法により，3種類の流量值の算定を行った。 ADCP推定流量【手法 I】が真值とみなされ, 電波式流 速計推定流量【手法 II 】は地形を洪水後横断測量から与 えた場合である。【手法III】はその折表案として，流速 については電波流速計による流速を用い，各時刻の地形 についてはADCPで計測したものを適用した.

\section{表-3 流量の算定方法}

\begin{tabular}{|l|l|}
\hline 【手法I】 & $\begin{array}{l}\text { ADCPで計測した横断面に対して直交方向の流速と } \\
\text { ADCPにより得られる河道地形から流量を算定する. }\end{array}$ \\
\hline 【手法II】 & $\begin{array}{l}\text { 電波式流速計で測定した表面流速に対して, 横断測量 } \\
\text { (排砂後の下黒部橋直下断面)と水位から算定される河積 } \\
\text { ら水深平均流速をり流定する場合のる.更正係数は先に求めた } \\
\text { 逆算更正係数0.89を用いる. }\end{array}$ \\
\hline 【手法III】 \\
$\begin{array}{l}\text { 電波式流速計で得られた流速と更正係数により水深 } \\
\text { 平均流速を算定し, ADCPにより得られた河道地形から } \\
\text { 流量を算定する. }\end{array}$ \\
\hline
\end{tabular}

（2）流量の推定

【手法 I 】，【手法 II】から推定したmain流路の流量 時系列を図-13に示す. 全体の変動傾向は一致するが, 観測期間の前半では相違が大きく，真值とみなされる

【手法 I 】の流量を基準とした場合の相違は最大で30\% 程度に及んだ(図-14).

この要因として，【手法 I】では各時刻の地形を考慮 しているが，【手法II】では洪水後測量の地形を一律与 えていることによる河積の相違が影響していると考えら れる. 図-15に，【手法 I】，【手法II】で用いている河 積の時間変化を示したが，流量の相違があった時間帯と 河積に相違がある時間帯は一致していることがわかる. つまり, 河床変動による地形の変化を考慮しないことが 流量の相違として大きく表れることが分かった.

【手法III】により, 時々刻々の河床変動状況を考慮し た上で，電波式流速計から流量を算定すると，図-16の とおり，【手法 I】，【手法III】はの相違は最大でも 10\%以下に留まり，ほぼ一致することを確認した。

\section{（3）愛本地点流量と下黒部橋地点流量}

黒部川では13.4km地点の愛本観測所において水位・流 量の連続観測を実施している. 図-17に愛本地点流量と $\mathrm{ADCP}$ ・電波式流速計により得られた下黒部橋の各流路 の合計流量を比較したものを示寸，なお，ADCPによる 流量観測はmain流路のみのため, 総流量算定にあたって, 他流路は電波式流速計により算定した各流路の流量を用 いて求めた.

総じて愛本地点流量とほぼ同等の流量ピーク值が得ら れていることがわかる. また，波形を比較してみると， 愛本地点流量を 1 時間遅らせた場合, 下黒部橋地点の観 測流量とほぼ一致する。つまり, 愛本地点からの流量遅 れ時間がおよそ1時間となっていることがわかった。 


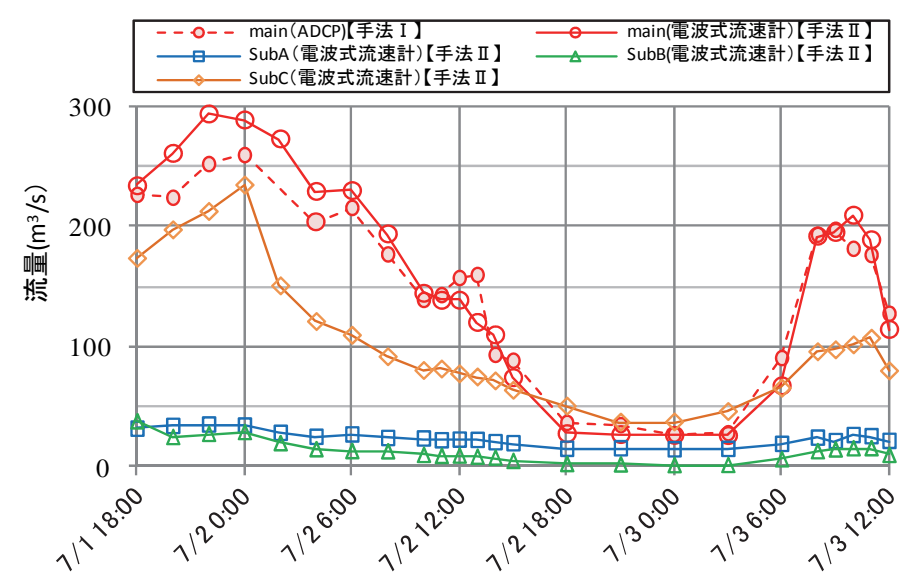

図-13 下黒部橋地点における推定流量

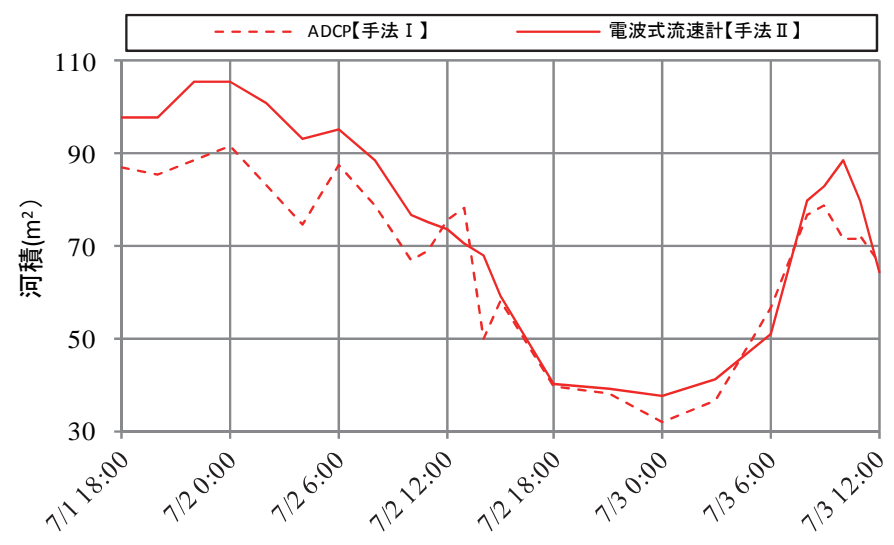

図-15 流量算定に用いた河積の時間変化

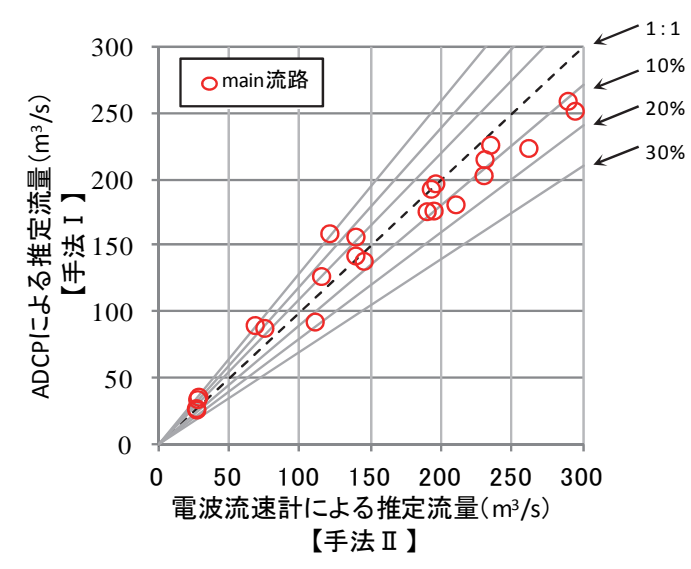

図-14 流量の比較（手法 I， II）

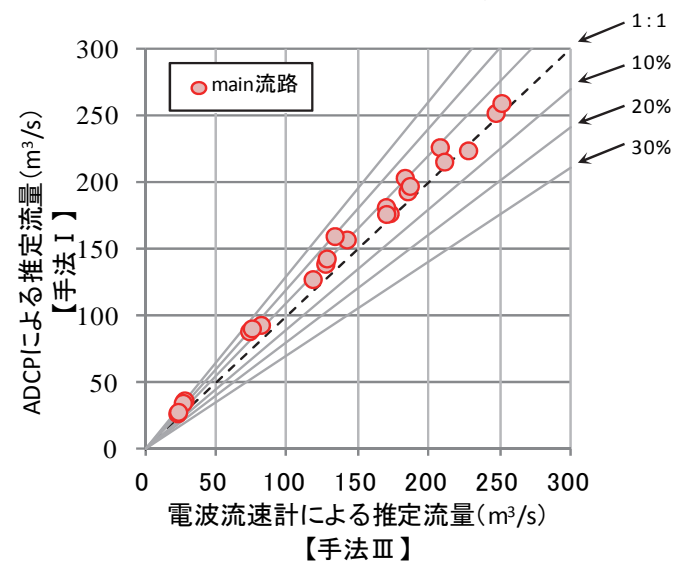

図-16 流量の比較 (手法 I, III)

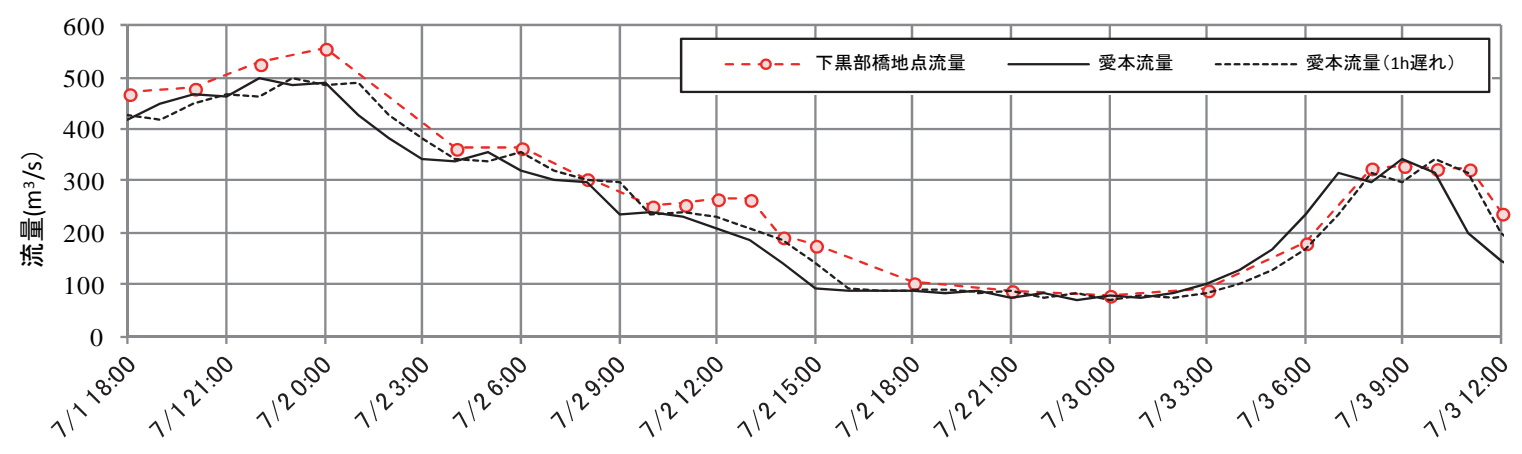

図-17愛本地点と下黒部橋における流量

\section{5. その他の知見}

本観測では，単発観測における高度観測"9の試みとし て，RTK-GPSを活用した河床移動速度の計測 ${ }^{10}$, ADCP 反射強度によるSS濃度の推定などについても実施した. ここでは後者について概説する。

\section{（1）反射強度を用いたSS濃度分布観測の可能性検討}

$\mathrm{ADCP}$ では流速とともに，超音波の反射強度を計測す ることが可能であり，この反射強度を活用することで， SS濃度分布を測定できる可能性を検討した.

各観測時に測定された水深別の反射強度を図-18に示 す．時間帯によって減衰率が異なっていることがわかる.
ここで，減衰特性を定量的に評価するため下式(1)によ って反射強度 $I$ の水深 $h$ に対する指数関数を近次式とし て適用する ${ }^{11)}$.

$$
I=C e^{-a h}
$$

ここで，C， $a$ は係数であり，特に $a$ は反射強度の減 衰を表寸減衰係数である. 反射強度の減衰は諸要因によ る伝播損失が生じていることによるが11)，洪水中のよう な高濁度時には, 濁度, 浮遊物質の粒径に依存すること が知られている11).

図-19に，式(1)より算出した減衰係数aと，表層採水試 料の室内分析で把握したSS濃度の時間変化を示す. SS 濃度が高くなっている時間帯では減衰係数が大きくなっ 
ており，対応関係が認められることから，粒径の違いな どを反映出来ない等の課題は残るものの, SS濃度の分 布を推定できる可能性はあると言える.

なお，一般的にADCPでは高濁度下では測定ができな いとされるが ${ }^{11)}$ ，今回計測ではSS濃度8,000mg/Lを含めて, 水深と反射強度の間には線形関係が成り立っており, 高 濁度に起因した欠測は生じていないことが確認できた。

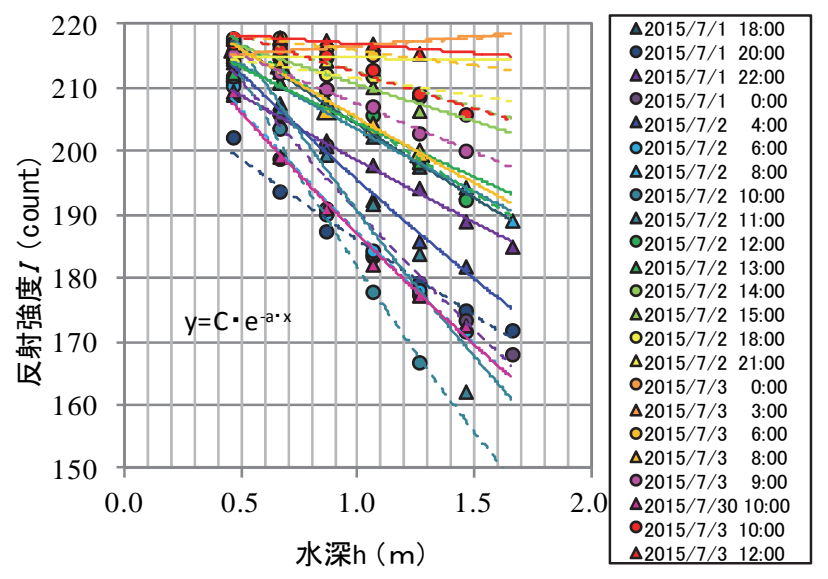

図-18 反射強度と水深の関係

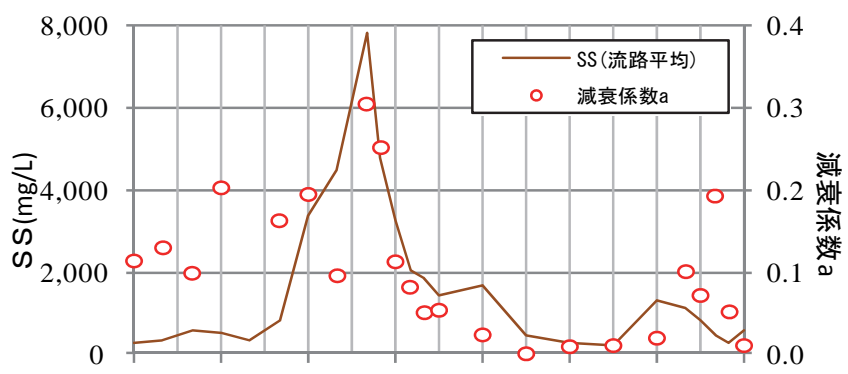

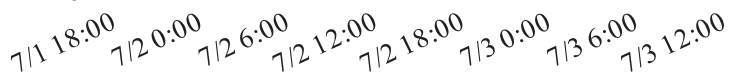

図-19 SS 濃度と反射強度の関係

\section{6. おわりに}

本稿で得られた主な知見は以下の通りである.

- 広く浅い流れが特徴の複列河道であっても, 観 測対象流路を選別し，ADCPにより往復で2回計 測したことで，欠測が大幅に軽減され，時間密 度の高い良好な観測が実施できた。

- $\mathrm{ADCP}$ 電波流速計の観測結果から更正係数を算 定すると，概ね一般的な値(0.85) と一致した.

- 主流路では連携排砂中の河床の上昇・下降が生 じており (変動幅 : 最大 $0.5 \mathrm{~m}$ ), 河床変動を考慮 しない場合と比べて，流量に最大 3 割程度の相違 が生じる。

- 時々刻々の地形変化を把握することによって電 波式流速計による表面流速の把握によって精度

\section{よく流量の換算が可能である.}

以上の知見から, 河道が固定化している条件下におい ては, 今後の複列河道における流量観測手法として, $\mathrm{ADCP}$ にる流量観測を行うことはもちろん可能である が，観測作業の省力・省コストのための方策として，電 波式流速計による表面流速の計測とソナ一等による地形 把握の組合せによる手法も採用可能と考える. また, こ れらの知見については，下黒部橋地点に限ったものでは なく, 国内では砂洲・澪笳の固定化が進んでいる箇所が 多いことから，この状況を逆手にとることで，複列河道 での効率的な流量観測も可能であることを提案していき たい.

謝辞 : 黒部河川事務所の方々には, 現地観測の許可, データ提供等の面で多大なご協力をいただいた，記して 謝意を表します。

\section{参考文献}

1) 高椋恵,岩本演崇, 秋田麗子, 手計太一：洪水時高濁度下 における ADCP による流量把握の試み,河川技術論文 集,第 18 巻,2012,pp.387-392.

2) 二瓶泰雄,色川有,井出恭平,高村智之：超音波ドップ ラー流速分布計を用いた河川流量計測法に関する検 討,土木学会論文集 B,Vol.8,No.2,pp.99-114,2008.

3) 岡田将治,萬矢敦啓,橘田隆史：日本における ADCP を 用いた流量観測データの品質管理手法の考察,河川流 量観測の新時代,第 2 巻,2011.

4) 萬矢敦啓,大平一典,菅野裕也,深見和彦: 非接触型電 波式流速計を用いた洪水流量自動観測手法の一考察, 土木学会河川技術論文集,Vol.16,pp.53-58,2010.

5) 山口高志,新里邦生: 電波流速計による洪水流量観測, 土木学会論文集,No.497／II -28,pp.41-50,1994.

6) 国立研究開発法人土木研究所 水災害・リスクマネジ メント国際センター,流量観測の高度化マニュアル(高 水流量観測編) Ver1.1,2015.

7) 二瓶泰雄,酒井雄弘: 実河川洪水流における浮子の更 生係数,土木学会論文集 B,Vol.66,No.2,pp.104-118,2010.

8) 根岸大介, 二瓶泰雄,片山直哉,柏田仁 : 電波流速計の 流速 - 流量計測精度の検討, 土木学会論文集 B,Vol.70,No.4,pp.1_625-1_630,2014.

9）橋場雅弘, 甲斐達也,津田哲也, 土田宏一: 河川流量観測 の高度化に対する観測実務者からの視点, 河川流量観 測の新時代,第 4 巻,pp.39-47,2014.

10) 岡田将治,竹内慈永,和泉征良, 萬矢敦啓, 橘田隆史: ADCP と RTK-GPS 搭載橋上操作艇を用いた定点・曳 航観測から得られた水深平均流速, 摩擦速度および掃 流砂速度の考察,河川技術論文集,第 20 巻,pp.6166,2014.

11) 二瓶泰雄,岩本演崇, 谷古宇洋介：H-ADCP の有効計測 範囲の検討,水工学論文集,Vol.54,pp.1099-1104,2010.

(2016. 4.7 受付) 


\section{PROPOSE THE FLOW DISCHARGE MEASUREMENT DURING SMALL FLOODS IN MULTIPLE ROW STREAM}

\section{Yoshiki NOMAGUCHI, Shiho NAKAMURA, Reiko AKITA and Taichi TEBAKARI}

The study team found that the sediment balance study considering the recession and delay of flow curve showed a $10 \%$ of difference between actual condition at the river mouth and Aimoto gauging station at the cooperating flushing in 2015.

This study described that the field observation, which was based on the previous observation study carried out in 2011, with three additional considerations; i) using speed boats and two way observations, ii) improving efficiency using multi observation methods by selection of targeted water channel corresponding to the water depth, iii) clarify the impact on the flow recession due to turbidity.

The study team also found that the relationship between surface flow velocity and cross-sectional average flow velocity is almost same by using the coefficient of float which was based on the traditional methods. Further, once the topographic conditions and water level is known, it is simple to estimate the stream flow using surface water flow.

Some proposals are also discussed for field observations. 